\title{
Research on Strategies for Improving Academic Innovation Service of University Libraries Under the New Media Environment
}

\author{
Ziyuan $\mathrm{Mi}^{1{ }^{1}}{ }^{*}$ Kening Ding ${ }^{1}$ \\ ${ }^{1}$ Library, Zhuhai College of Jinlin University, Zhuhai, Guangdong 519041, China \\ "Corresponding author. Email: 281432546@qq.com
}

\begin{abstract}
With opportunities and challenges to academic information service of university libraries brought by the new media age, how to effectively use new media to provide users with high-quality academic information service has become an urgent problem to be solved in the field of library. Based on this, this paper explores the innovative service mode of university libraries under the new media environment, and seeks strategies and ways to improve the academic information service quality of university library. From the perspective of user needs and service methods, this paper discusses the various types of user needs and different service modes of university libraries under the new media environment. It analyzes the academic innovation service model of university library embedded in the process of scientific research from the aspects of the connotation and characteristics of service model and specific process of service. Starting from the service subjects, users, academic information resources, new media platform and service environment of university libraries, this paper puts forward corresponding countermeasures and suggestions for academic innovation service of university libraries under the new media environment.
\end{abstract}

Keywords: new media, university libraries, academic information services, user demand, embedding scientific research process, innovative service mode, promotion strategy

\section{INTRODUCTION}

With the rapid development of mobile Internet technology and mobile terminal technology, the new media platform based on social media has rapidly penetrated into all aspects of people's life with its advantages such as convenient access, powerful interactive function and rapid spread, becoming an important way for people to obtain information resources, express personal views and interact with each other. University libraries, as the main scientific research service subjects, undertake the important task of assisting users to carry out scientific research activities. In the past, academic information service of university libraries had the problems of single service mode and means, communication barrier between users and librarians, and low user attendance rate, etc. With the advent of the new media age, university libraries have started to use WeChat and other new media platforms to push academic resources, enrich and expand academic service functions, enhance user stickiness and expand their academic influence [1]. Under the new media environment, how to further develop and innovate the service mode of university libraries, constantly improve the service quality, improve the satisfaction of users, and bring more highquality academic service content to users has become an urgent problem to be solved in the field of library.

\section{THE USER DEMAND TYPE AND SERVICE MODE OF UNIVERSITY LIBRARY UNDER THE NEW MEDIA ENVIRONMENT}

\section{A. The user demand types of university library under the new media environment}

The process in which users use university libraries to obtain academic information services is the process in which users' needs are constantly generated and satisfied. With the improvement of users' cognitive level, especially in the context of new media, users gradually evolve from a single academic information need to a variety of needs. In addition to basic academic information needs, users have higher requirements on interface design, system interaction, emotional attitude and social interaction of Weibo and WeChat platforms in university libraries. On the basis of Maslow's hierarchy of needs and user experience demand theory, the user demand of university library under the new 
media environment is divided into information demand, feeling demand, interaction demand, emotion demand and social demand.

1) Information demand: It refers to users' demand for academic information resources in university libraries. It is the source power to stimulate users' information behavior and carry out information activities in university libraries. Meanwhile, providing users with academic information resources is also the most basic and practical service function of university libraries.

2) Feeling demand: Good sensory experience will make users happy and enhance their willingness to continue using.

3) Interaction demand: It is the requirement of interaction in the process of user operation of university library platform, and it is a requirement for system performance, efficiency, and service level.

4) Emotion demand: As an important factor for users to generate information, affect users' willingness to use and guide their decisions. Whether university libraries can make users love and continue to use directly affects the stickiness of users and academic influence of university libraries.

5) Social demand: It is users' demand for social relations due to interactive communication. Under the new media environment, university libraries have strong social properties.

\section{B. Information service mode of university library under the new media environment}

Under the new media environment, university libraries continue to enrich and innovate service methods and means, including reference service, subject service, new book bulletins and bibliographic guidance.

1) Reference service: University librarians establish weibo or WeChat platforms to form reference microgroups or thematic knowledge bases with clear division of labor, so as to allow users to quickly consult and search literature resources or assist them to make decisions by consulting relevant scientific research issues.

2) Subject service: In the past, the subject service often failed to contact and fully communicate with users in time, leading to the lag of service. The new media platform builds a bridge between subject librarians and users. Subject librarians update the research trends of subjects in real time through the platform, so as to timely understand the information needs and research trends of users, and users communicate with subject librarians through the platform.
3) New book bulletins and bibliographic guidance: In the era of rapid updating of knowledge, it is particularly important for users to obtain the latest books and materials in the first time. New media platforms can timely push the information of new library collections to users, and guide users' bibliography reading online according to their personalized information needs through the platform.

\section{THE INNOVATIVE SERVICE MODE OF EMBEDDING SCIENTIFIC RESEARCH PROCESS IN UNIVERSITY LIBRARY}

The university library information service embedded in the process of scientific research integrates into the user environment, provides users with professional and precise academic information service through the new media platform, and assists users to complete scientific research tasks. The university library service mode embedded in the scientific research process is an innovative service mode embedded in the entire scientific research process of users. It takes the new media platform as the window for information resource acquisition and communication, pays close attention to users' needs in real time, fully communicates with users, and improves users' scientific research efficiency [2].

The process of university library information service embedded in the process of scientific research includes the stages of setting up a service team and embedding in the stages of scientific research project approval, planning, implementation and project conclusion.

\section{- Setting up a service team}

Before carrying out embedded services, university libraries need to set up a service team with professional quality and service communication ability to avoid the incompleteness of single service personnel and realize timely push of academic information resources, timely tracking of scientific research trends and active communication with users through team cooperation [3].

\section{- Embedding in the stage of project approval}

The service team of university library can know the progress of users' scientific research in real time through the new media platform, and provide corresponding services according to the situation of scientific research projects. The service team collects a large amount of literature materials and domestic and foreign research hotspots of the corresponding topics according to users' needs, and actively pushes predictive and evaluative information to users through the new media platform, so as to provide reference information for users to apply for projects. 


\section{- Embedding in the stage of project planning}

The service team mainly provides reference consulting services, inserts the planning process of users, uses the platform to regularly push some resources related to project planning and scheme formulation, sets up expert online reference consulting function, communicates with experts in real time through the platform [4], and timely adjusts and improves the planning scheme.

- Embedding in the stage of project implementation

The service team should embed the research process of users and assist users to solve problems in the process of scientific research.

\section{- Embedding in the stage of project conclusion}

The service team helps users to sort out the research results related to the project, assists in report writing and material review, and screens and evaluates the research results with the permission of users, so as to further expand the dissemination scope of results and the academic influence of users.

\section{PROMOTION STRATEGIES FOR ACADEMIC INNOVATION SERVICE IN UNIVERSITY LIBRARIES}

Currently, university libraries have realized the important role of new media platform in academic information service of library, but they are still in the exploratory stage. Since the participation threshold of the new media platform is low, university libraries have applied to open the library's weibo or WeChat public platform account. However, due to the lack of professional service teams, appropriate service contents and corresponding operation and management methods, many new media platforms in university libraries only stay in the opening stage, with many problems such as delayed information update, single function and low number of users, and lack of service methods and strategies suitable for the new media environment. If the platform is only used as an information window to push activity notification, it will hinder the sustainable development of new media platform of university libraries [5]. On the basis of exploring the user demand and service mode of university library under the new media environment, starting from the service subjects, users, academic information resources, new media platform and service environment of university libraries, the author puts forward corresponding countermeasures and suggestions in order to improve the academic service quality of university libraries under the new media environment.

\section{A. Meeting the diversified user demands, with user as the center}

University library information service should continuously deepen the user-oriented service concept, and explore the user rules from the aspects of user demand, user expectation, user experience and user perception and evaluation, so as to guide the direction and guide of library service. As the goal and purpose of librarians' service work, service concept is the dominant thought in academic service activities and the basic criterion to regulate academic service activities and information behavior of service personnel [6]. With the increasing awareness of user subjects and the increasingly fierce competition of new media platforms, university libraries should establish a user-centered service concept, actively adapt to the new media environment, and observe and meet the diverse needs of users.

All service personnel in university libraries should carry out service activities around users, collect information resources and design service contents from the perspective of user needs, and publish the sorted and processed contents to the new media platform for users' convenience. Academic information service of university libraries in the context of new media should not limited to document service, but more importantly, it needs to deeply understand users' needs and provide users with knowledge services [7]. Before the library information service is carried out, sufficient demand collection and demand analysis should be carried out. As different types and disciplines have different contents of user demands, it is necessary to collect, sort out and analyze the demands of different levels of scientific research user groups through questionnaire survey, user interview and other methods, so that a systematic demand system can be formed, and the service subject can guide the service work of new media platform of university library according to the acquired demand model. In addition, it is necessary to dynamically observe the changes of users' demands and the degree of satisfaction of their demands in the process of use, timely adjust service strategies, and gradually explore the potential demands of users to improve their satisfaction.

\section{B. Comprehensively improving the academic service ability of university libraries}

As a new academic service platform, the new media platform created by university libraries is more suitable for the current way that users obtain information and services by using mobile terminals anytime and anywhere. If the Weibo and WeChat platforms of university libraries are to be continuously developed and attract the attention of many scholars, the first thing is to comprehensively improve their academic information service ability on the basis of clear service positioning. The level of service ability directly 
determines the development level and competition ability of university libraries. So it is necessary to set up a professional and high-quality service team and innovate service mode constantly.

The work of the university library new media platform service team mainly includes information collection and push, interaction and communication with users, and platform operation and maintenance, etc. [8]. In terms of information collection, there are many valuable pieces of information in the current academic field, which are updated very quickly, and there are many resource acquisition channels owned by university libraries. Therefore, modern information collection technology should be used to grasp the research frontier and research results in time [9]. The interactivity of the new media platform provides great convenience for the interactive communication between university libraries and users, and between users. In terms of interactive functions and interactive ways, it should be more in line with users' psychology and behavior habits. In addition to the service content, service subjects should also pay attention to the operation and management of the platform to avoid following suit and blindly opening new media platforms. It is necessary to set up a professional new media platform management team in university library, be equipped with strong new media platform operation thinking, and comprehensively improve the service ability from the platform's early preparation, development and design, function setting and platform promotion, so as to ensure sufficient human and material support. In addition, it is necessary to strengthen the publicity of the new media platform of university libraries to increase their awareness and attention.

\section{Promoting interaction between users and the platform and between users and users}

The academic information service of university libraries depends on the participation of users. The number and degree of user participation are important factors to measure the service quality of new media platform of university libraries. Compared with the traditional library academic service, the university library service under the new media environment effectively integrates the academic and new media attributes, and the user's participation has gradually become the focus of the service subject. How to attract users to participate, extend the time of user participation and improve the degree of user interaction is the important guarantee for the sustainable development of new media platform of university library.

University libraries need to adopt certain incentive mechanism and management mechanism to stimulate users' willingness to actively generate content and participate in interaction. In addition, users will be given certain material or spiritual rewards, such as user ratings, points or honorary titles, and some online academic activities or academic conferences and lectures will be organized regularly to attract users to sign up for watching live videos, and one-to-one question-asking exchanges with experts can be conducted by voice. Through the new media platform, users can take advantage of the fragmented time to obtain academic resources within the platform and interact with the service subjects and other research users in the platform in real time, which is not only conducive to improving their own academic knowledge, but also can promote the construction of academic relationship network.

\section{Enriching the form of academic information resources and attaching importance to the quality of knowledge content}

Academic new media information resource is the content carrier of users' demands [10], the final result provided to service objects by the subject of academic new media information service, and is the basic premise and important support for information interaction between users and platforms, users and users as well as platforms. As digital information content related to academic research tasks or research fields, information resources is the basis of academic information service in university libraries, which can be used to assist users in academic research and ensure the smooth progress of academic activities.

Compared with traditional academic services, new media platforms are more diversified in the expression forms of academic resources [11], mainly including text, charts, pictures, voice, video and hyperlinks, etc. Service subjects can choose one or several ways of combining the forms. At the same time, the advantages and disadvantages of each form in terms of difficulty of content generation, efficiency of information transmission, information contained capacity and capital cost should be taken into account. In terms of types, the academic resources mainly include cuttingedge information, conferences and lectures, literature materials and experience, etc. It is necessary to make full use of the remarkable advantages of university libraries in resource channels, expert teams and financial support to screen and provide users with some academic resources that are difficult to obtain, costly in money and of high quality.

\section{E. Realizing collaborative system service and improving academic influence}

When college libraries choose new media platforms, different new media platforms have different focuses in terms of specific service functions set up, information content frequency pushed, technical means adopted and 
user groups owned, playing different service functions. The information content, service function, technical means and academic influence pushed by WeChat public platform have attracted a large number of users to participate in. In addition to pushing academic information resources, WeChat public platform has also continuously expanded the functions and interaction forms of scientific research service, gradually becoming a new mobile academic service platform. Mobile library APP is a new media platform formed by combining the characteristics of mobile terminals on the basis of PC terminal library website, which mainly meets the supply of resources and auxiliary functions of scientific research. Weibo and WeChat have obvious advantages in information dissemination and promotion, user participation and real-time interaction, etc. Mobile library APP focuses on resource sharing and function design, but not in terms of interaction and communication influence. Within the scope of their abilities, university libraries should organically combine different new media platforms to provide coordinated and systematic new media services. In addition, the university library service subject should face up to the interdependent relationship between users and library, release academic information resources rich in academic value, develop more practical academic service functions and constantly improve the quality of academic information service, promote a virtuous circle between user benefit and library benefit, so as to realize mutual benefit and win-win between the service subjects and users of library.

\section{CONCLUSION}

The deep integration of new media and university libraries is the reform and innovation of academic services of university libraries, which is conducive to breaking through the limitation of time and space in academic information services of university libraries and providing users with richer and more accurate service content. This is both an opportunity and a challenge for university libraries. Users' use and dependence on mobile new media is the foundation for university libraries to share information resources and provide academic services by using new media platform. Based on the analysis of the user demand type and service mode of university library under the new media environment, this paper proposes an innovative model of university library information service embedded in scientific research process. Finally, it puts forward corresponding strategies for improving the academic service quality of university libraries from the perspectives of building a customer-oriented service concept, meeting user needs, enhancing academic service ability in an all-round way, promoting interaction between users, enriching the form of information resources, focusing on information quality and personalized service, optimizing interface design and interaction functions, implementing collaborative system services, creating an atmosphere of academic research, and strengthening inter-library cooperation, etc., which provides theoretical support and reference for academic information service of university libraries under the new media environment.

\section{References}

[1] Huang Run. New Media and the Innovation of Information Service in University Libraries [J]. Journal of Academic Library and Information Science, 2009, (1): 77-79, 93. (in Chinese)

[2] Li Yang, Pei Li. Practice and Enlightenment of Embedded Research of University Library Information Service [J]. Chinese Journal of Library and Information Science for Traditional Chinese Medicine, 2014, (04): 33-36. (in Chinese)

[3] Chen Quansong. Practice and Thoughts of Embedded Subject Service Model in University Libraries — Taking Xiamen University Library as an Example [J]. Library and Information Service, 2012, (07): 83-87. (in Chinese)

[4] Chen Lianfang, Xu Chunman. Research on Embedded Innovative Service Model of University Library [J]. Library Work and Study, 2010, (08): 4-7. (in Chinese)

[5] Guo Jun. Investigation and Analysis of the Service Status of "985" University Library Based on WeChat Official Platform [J]. (in Chinese) Research on Library Science, 2015 (4): 71-76. (in Chinese)

[6] Wu Longlong, Yang Xiaoju. Research on University Mobile Library Service Based on WeChat Public Platform [J]. Research on Library Science, 2013(18): 57-61.51. (in Chinese)

[7] Du Hui, Liu Xiao, Yuan Baicheng. University Library Subject Service Innovation Based on WeChat Public Platform [J] Library and Information Service, 2015(6): 41-45. (in Chinese)

[8] Fu Kaili. Design of Scientific information Service Platform in University Libraries Based on User Needs [J]. Journal of Modern Information, 2016, 36(4): 101-104,114. (in Chinese)

[9] Yang Fujin, Chen Jiayong, Xiao Ming. Research on University Library Information Service Platform Based on Academic Information Demand [J]. Library Theory and Practice, 2015(8): 83-86. (in Chinese)

[10] Madge O L. Reaching out to Users: Romanian Academic Libraries on Facebook [J]. Qualitative \& Quantitative Methods in Libraries, 2015: 855-859.

[11] Vassilakaki E, Garoufallou E. Library Facebook practices for creating and promoting a professional profile [J]. Program, 2015, 49(3):343-359. 